\title{
L-ascorbic acid-2-phosphate and Fibrin Substrate Enhances the Chondrogenic Differentiation of Human Adipose-derived Stem Cells
}

\author{
Imam Rosadi ${ }^{1,2}, *\left({ }^{\oplus}\right.$, Karina Karina $^{2,3,4,5}$, Viol Dhea Kharisma ${ }^{6,7}$, Arif Nur Muhammad Ansori ${ }^{8}$
}

${ }^{1}$ Department of Biology, Faculty of Mathematics and Natural Sciences, Mulawarman Univeristy

${ }^{2}$ HayandraLab, Yayasan Hayandra Peduli, Jakarta, Indonesia

${ }^{3}$ Klinik Hayandra, Yayasan Hayandra Peduli, Jakarta, Indonesia

${ }^{4}$ Universitas Pembangunan Nasional Veteran Jakarta, Depok, Indonesia

${ }^{5}$ Pusat Kajian Stem Cell, Universitas Pembangunan Nasional Veteran Jakarta, Depok, Indonesia

${ }^{6}$ Master Program in Biology, Department of Biology, Faculty of Mathematics and Natural Sciences, Brawijaya University, Malang, Indonesia

${ }^{7}$ Generasi Biologi Indonesia Foundation, Gresik, Indonesia

${ }^{8}$ Doctoral Program in Veterinary Science, Faculty of Veterinary Medicine, Universitas Airlangga, Surabaya, Indonesia

Correspondence

Imam Rosadi, Department of Biology, Faculty of Mathematics and Natural Sciences, Mulawarman Univeristy

HayandraLab, Yayasan Hayandra Peduli, Jakarta, Indonesia

Email: imamrosadi@unmul.ac.id

History

- Received: Sep 11, 2021

- Accepted: Nov 09, 2021

- Published: Dec 312021

DOI : 10.15419/psc.v8i2.412

\section{Check for updates}

\section{Copyright}

(๑) Biomedpress. This is an openaccess article distributed under the terms of the Creative Commons Attribution 4.0 International license.

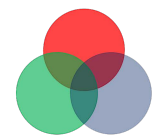

BioMedPress

The Open Access Publisher

\begin{abstract}
Background: Adipose-derived stem cells (ASCs) have been developed as a substitute for chondrocytes in cartilage tissue engineering. This study aimed to evaluate the potency of ascorbic acid to induce the chondrogenic differentiation of human ASCs cultured on fibrin substrate. Methods: Human ASCs were isolated by an enzymatic process and characterized. The fibrin scaffold was fabricated from human blood as a natural scaffold. The ASCs were cultured in $10 \%$ fetal bovine serum (FBS) supplemented by ascorbic acid in various concentrations $(1,3,6 \mu \mathrm{g} / \mathrm{ml})$ and a control without an ascorbic acid supplementation. The chondrogenic differentiation of the ASCs was evaluated involving glycosaminoglycan analysis, and the mRNA expression of type 2 collagen, aggrecan and type 1 collagen. Results: Chondrogenic differentiation occurred when the ASCs were supplemented by $3 \mu \mathrm{g} / \mathrm{ml}$ of ascorbic acid and cultured on a fibrin scaffold confirmed by glycosaminoglycan (GAG) analysis, and the mRNA expression of type 2 collagen and aggrecan. The expression of type 1 collagen, which is an osteogenic marker, was low. Conclusions: ASCs with a supplementation of $3 \mu \mathrm{g} / \mathrm{ml}$ of ascorbic acid cultured on a fibrin substrate promotes chondrogenic differentiation.
\end{abstract}

Key words: ASCs, L-ascorbic acid-2-phosphate, chondrogenesis, fibrin, differentiation

\section{INTRODUCTION}

Mesenchymal stem cells (MSCs) are multipotent cells and they have an important role in regenerative medicine therapy ${ }^{1}$. The most common source of MSCs are the bone marrow and adipose tissue ${ }^{2,3}$. However, due to the invasive risk of cells being harvested and the low yields from bone marrow, adipose tissue is more studied nowadays ${ }^{4}$. The MSCs isolated from adipose tissue are called adipose-derived stem cells (ASCs). ASCs were first reported by Zuk et al. along with their ability to differentiate into several different types of cell ${ }^{5,6}$.

The proliferation and differentiation of ASCs depends on their niche (microenvironment) and substrate ${ }^{7}$. In low oxygen tension $\left(<1 \% \mathrm{pO}_{2}\right)$ for two days, the ASCs morphology changed and the expression of SRY-box containing gene 9, aggrecan and collagen type II mRNA levels was enhanced ${ }^{8}$. In addition, the supplementation of vitamin $\mathrm{C}$ (ascorbic acid) also supports the proliferation of $\mathrm{ASCs}^{9}$, preventing the cells from aging because the ascorbic is antioxidant ${ }^{10}$, alongside induced cell differentiation into chondrogenic or osteogenic ${ }^{9,11}$. Chondrogenic differentiation leads to the cells expressing glycosaminoglycan, type 2 collagen and aggrecan while osteogenic differentiation leads the cells to express type 1 collagen ${ }^{\mathbf{1 2}}$. Ascorbic acid itself is a cofactor that can increase collagen production and synthesize the extracellular matrix (ECM) of cells in an optimal concentration ${ }^{13}$. The elevated concentration of ascorbic acid in a cell culture medium inhibits cell proliferation and induces cell apoptosis ${ }^{14,15}$. The optimal concentration of ascorbic acid needs to be evaluated as a result. Fibrin substrate is a natural material substrate that is collected from human blood ${ }^{\mathbf{1 6}, 17}$. Its potency to support cell attachment plays a role in the proliferation and differentiation of cells ${ }^{18}$.

Fibrin as substrate secretes protein that affects the cellular activity. It can be fabricated for the purpose of constructing tissue engineered cartilage ${ }^{16,19}$. However, the combination of ascorbic acid and fibrin substrate to support proliferation and the chondrogenic differentiation of human ASCs is still unclear. In this study, we evaluate the effect of ascorbic acid on the chondrogenic differentiation of ASCs cultured on fibrin substrate.

\section{METHODS}




\section{Isolation and culture stromal vascular frac- tion}

The stromal vascular fraction (SVF) cells were isolated from the lipoaspirate of one donor using an enzymatic method followed by the previous method ${ }^{20,21}$. The protocol was approved by the Ethical committee of Dharma Nugraha Hospital (No.: 001/SkeIKom/RSDN/I/2020) and informed consent was taken from all individual participants. As much as $10 \%$ H-Remedy enzyme was added to the lipospirates and they were incubated for 1 hour at $37{ }^{\circ} \mathrm{C}$ at $300 \mathrm{rpm}$. To inactivate the enzyme digestion process, low-glucose $(1 \mathrm{~g} / \mathrm{L})$ Dulbecco's modified Eagle's medium (DMEM) containing 4mML-glutamine (Gibco, USA) was added to the lipoaspirates followed by centrifugation for $5 \mathrm{~min}$ at $600 \times \mathrm{g}$. The supernatant was discarded and the pellet SVF was then diluted in a saline solution. The cell number and viability were counted using the tryphan blue staining methods. Isolated cells were cultured in a basic growth medium (DMFA) containing low glucose (1 g/L) DMEM with L-glutamine (4 mM) (Gibco, USA), fetal bovine serum, and 100X antibiotic-antimycotic (Gibco, USA). They were then incubated at $37{ }^{\circ} \mathrm{C}, 5 \%$ $\mathrm{CO}_{2}$. After reaching $80-90 \%$ confluency, the cells were sub-cultured and expanded to passages 2 and 3 to be used in further assays.

\section{Cell morphology}

To investigate the effect of L-ascorbic acid 2phosphate (Sigma-Aldrich, USA) on ASCs, cells were cultured in DMFA only as a control, and in DMFA with L-ascorbic acid 2-phosphate $(1 \mu \mathrm{g} / \mathrm{ml}, 3 \mu \mathrm{g} / \mathrm{ml}$, and $6 \mu \mathrm{g} / \mathrm{ml})$. Passage 3 of cells $\left(5 \times 10^{3}\right.$ cells) were then cultured in a 24-well plate. After 9 days of culture, the images were captured (Optica, Italy).

\section{Fabrication of the fibrin substrate}

The fibrin was obtained from Klinik Hayandra as a waste product of platelet-rich plasma. The fibrin was fabricated according to Kobayashi et al., ${ }^{22}$. The weight of the freshly prepared, compression and overnight incubation at $37^{\circ} \mathrm{C}$ of fibrin was measured. The incubated fibrin was then cut into $5 \times 5 \mathrm{~mm}$ as a substrate cultured in a 96-well plate (Figure 1).

\section{In vitro degradation of fibrin}

The fibrin was cut into $5 \mathrm{~mm} \times 5 \mathrm{~mm}$ and the fibrin weight was measured. The fibrin was immersed in PBS ( $\mathrm{pH}$ 7.0) (Lonza, USA) as a control and in Tryple select $1 \mathrm{X}$ (Gibco, USA) as a treatment group. It was then incubated at $37^{\circ} \mathrm{C}$ for 21 days. After 21 days of incubation, the fibrin weight was measured.

\section{Chondrogenic differentiation assays}

The ADSCs at passage 3 were cultured on fibrin ( $1 \mathrm{x}$ $10^{5}$ ) in various media (DMFA, DMFA with $1 \mu \mathrm{g} / \mathrm{ml}$, $3 \mu \mathrm{g} / \mathrm{ml}$, and $6 \mu \mathrm{g} / \mathrm{ml}$ of ascorbic acid). The cells were analyzed on day 21 for the GAGs levels and the mRNA expression of type 2 collagen, aggrecan, and type 1 collagen.

\section{Glycosaminoglycans (GAG) analysis}

GAG analysis was conducted using alcian blue staining to stain the acidic polysaccharides, such as GAG. The cells were fixed in $4 \%$ paraformaldehyde for 15 min. The $4 \%$ paraformaldehyde was then removed and $1 \%$ alcian blue in $3 \%$ acetic acid was added to the fixed cells for $30 \mathrm{~min}$. The alcian blue was then removed and washed twice with PBS (Lonza, USA). The deionizing solution was then added and incubated for $2 \mathrm{~min}$. The washed cells were then mixed with $100 \mu \mathrm{l}$ of $1 \%$ sodium dodecyl sulphate (SDS) and mixed in a shaker at $200 \mathrm{rpm}$ for $30 \mathrm{~min}$. The GAG content was determined based on the absorbance value of the solution at a $595 \mathrm{~nm}$ wavelength on a microplate reader (iMark Bio-Rad).

\section{mRNA expression of the chondrogenic and osteogenic markers}

The cells of all groups were harvested on day 21 . RNA isolation was performed using the SV Total RNA Isolation System (Promega, USA) while the synthesis of cDNA and mRNA expression analysis were performed using the GoTaq 2-Step qPCR System (Promega, USA) according to the manufacturer. The amount of total RNA used to perform the reversetranscription and the cDNA synthesis was $67 \mathrm{ng}$. Gene amplification and the software used for the data analysis were performed by the CFX96 Touch RealTime PCR Detection System - Bio-Rad. The final amplification volume was $25 \mu \mathrm{L}$ with $1 \mu \mathrm{L}$ volume of cDNA used as the template.

The mRNA expressions analyzed were type 2 collagen, aggrecan, and type 1 collagen with GAPDH as the gene reference (Table 1). The cycle conditions were an initial denaturation step of $95^{\circ} \mathrm{C}$ for $2 \mathrm{~min}$, followed by 40 cycles of denaturation at $95^{\circ} \mathrm{C}$ for $15 \mathrm{~s}$, annealing at $54.4^{\circ} \mathrm{C}$ for $1 \mathrm{~min}$, and a final extension at $60-$ $95^{\circ} \mathrm{C}$ for $5 \mathrm{~s}$. The result of the qPCR was analyzed following the $2^{-\triangle \Delta C T}$ method described by Livak et al. $(2001)^{23}$.

\section{Statistical analysis}

The data from each parameter was presented as average \pm standard deviation (SD) in the tables and charts. 

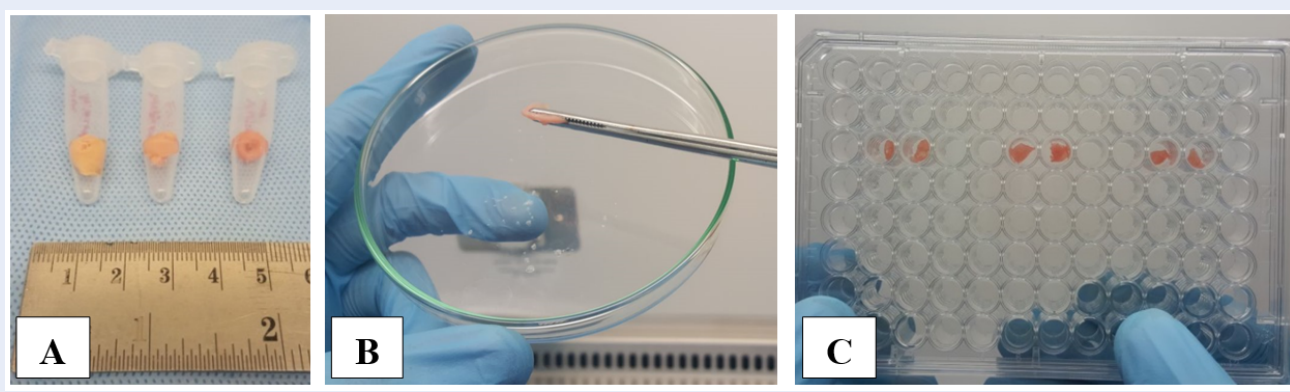

Figure 1: Freshly prepared of fibrin (A), compression (B) and fibrin substrate (C).

Table 1: Primer design

\begin{tabular}{lllcc}
\hline Gene & & Nucleotide base & Base number & $\begin{array}{c}\text { Amplicon } \\
\text { length (bp) }\end{array}$ \\
\hline GAPDH & forward & CAAGAGCACAAGAGGAAGAGAG & 22 & 102 \\
& reverse & CTACATGGCAACTGTGAGGAG & 22 & \\
Type 2 collagen & forward & GAACCCAGAAACAACACAATCC & 22 & 86 \\
& reverse & CATTCAGTGCAGAGTCCTAGAG & 21 & 104 \\
Aggrecan & forward & CAGAATGGGAACCAGCCTATAC & 22 & \\
& reverse & GCCTTCTGTACTTTCCTCTGTT & 22 & 100 \\
Type 1 collagen & forward & AGAGTGGAGCAGTGGTTACTA & 21 & 22 \\
& reverse & GATACAGGTTTCGCCAGTAGAG & 22 & \\
\hline
\end{tabular}

The differences were analyzed $(\mathrm{p}<0.05)$ using a parametric statistical test analysis of variance (ANOVA).

\section{RESULTS}

\section{Cell morphology}

There was slight difference in the cell morphology between the control group and the ascorbic acid supplementation groups. The cells were spread and attached tightly to the polystyrene substrate. The cell shape is represented on day 9 of the observation in Figure 2.

\section{Biodegradability of fibrin}

The decrease in fibrin weight when compressed and incubated shows that the fibrin substrate was successfully fabricated. This result was also previously reported by Kobayashi ${ }^{22}$. Compared to the freshly prepared wet weight, the compression and incubation was significantly reduced (Figure 3). The degradation of fibrin is shown in Figure 4. Fibrin that was incubated with PBS for 21 days showed no significant change while the fibrin that was incubated with Tryple Select $1 \mathrm{X}$ for 21 days was significantly reduced. Tryple degraded the fibrin substrate into small pieces. The percentage of degradation of the PBS group was 20\% of the weight while for Tryple, it was more than $90 \%$ of the weight.

\section{Chondrogenesis of ASCs}

GAGs content was observed in the ASCs cultured on the fibrin substrate (Figure 5). The groups with ascorbic acid supplementation that expressed the GAGs level abundantly had a blue color of an intensity compared to the control. The concentrations of $3 \mu \mathrm{g} / \mathrm{ml}$ and $1 \mu \mathrm{g} / \mathrm{ml}$ of ascorbic acid were the highest groups that expressed GAGs content followed by $6 \mu \mathrm{g} / \mathrm{ml}$ and the control.

\section{mRNA Expression}

Ascorbic acid induced type 2 collagen and aggrecan expression depending on its concentration. The highest level of type 2 collagen and aggrecan was present in the group of $3 \mu \mathrm{g} / \mathrm{ml}(5.11 \pm 0.31$ and $1.93 \pm 0.67)$ followed by $1 \mu \mathrm{g} / \mathrm{ml}$ (3.61 \pm 0.13 and $1.31 \pm 1.24)$, the control and $6 \mu \mathrm{g} / \mathrm{ml}(1.15 \pm 0.23$ and $0.40 \pm 0.29)$, respectively (Figure 6). There were significant differences in the type 2 collagen expression in the cells supplemented with $3 \mu \mathrm{g} / \mathrm{ml}$ and those supplemented 

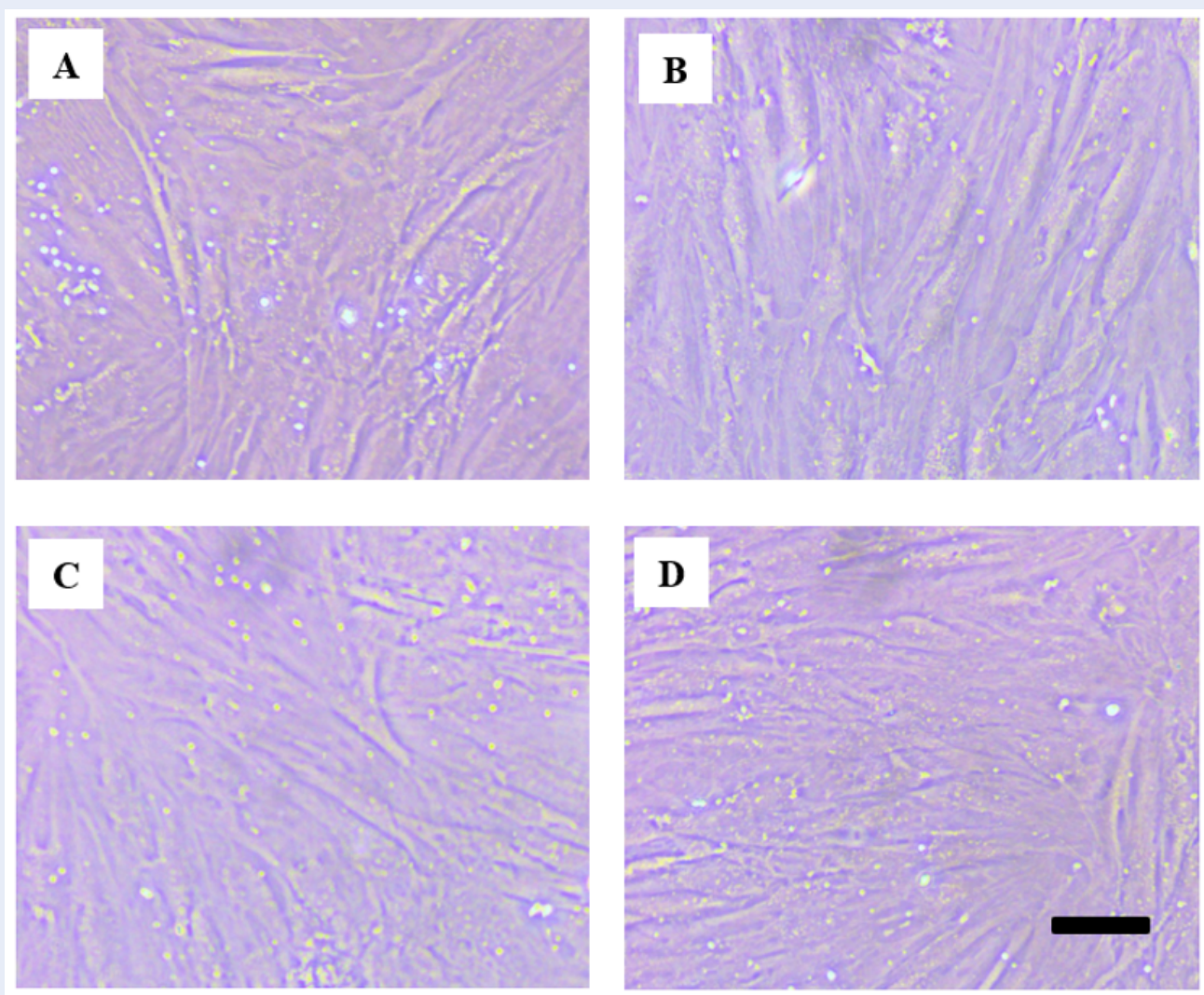

Figure 2: Morphology of cells with/without ascorbic acid on day 9 of observation, control (A); $1 \mu \mathrm{g} / \mathrm{ml}$ of ascorbic acid; $3 \mu \mathrm{g} / \mathrm{ml}$ of ascorbic acid; $6 \mu \mathrm{g} / \mathrm{ml}$ of ascorbic acid; black bar $=100 \mu \mathrm{m}$

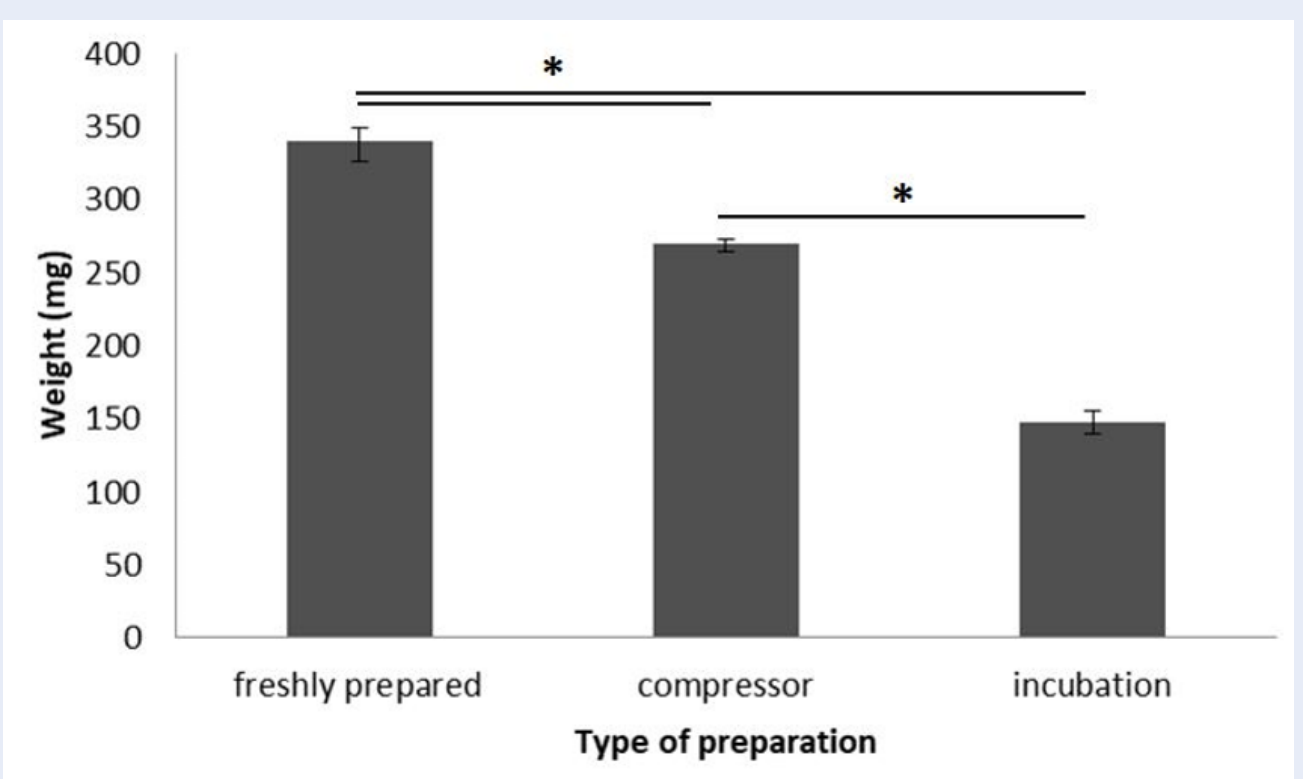

Figure 3: The decrease of wet weight of fibrin during compressor and incubation overnight $\left(37^{\circ} \mathrm{C}\right) .{ }^{*} \mathrm{p}<$ 0.05 indicates statistical significance. 

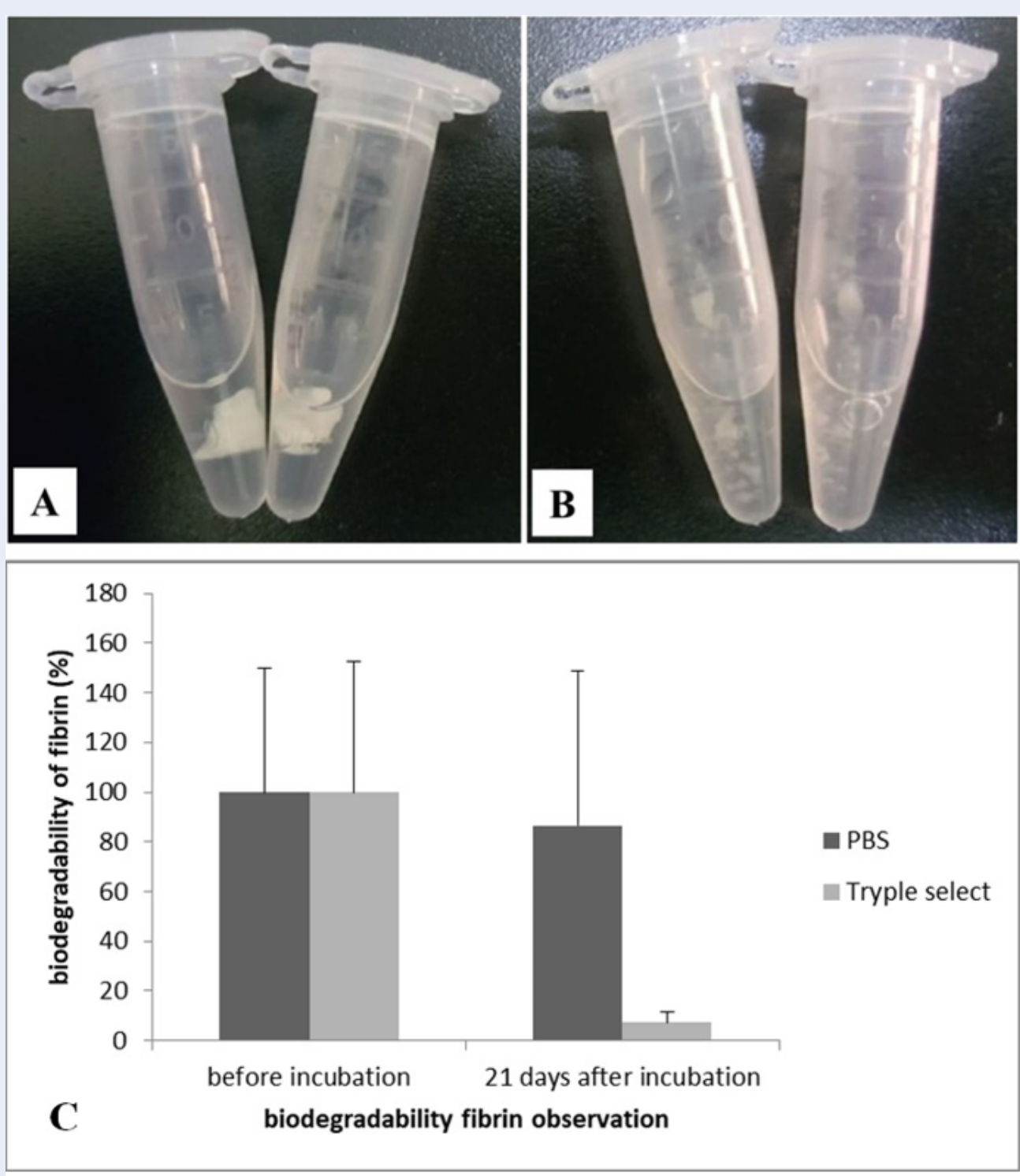

Figure 4: Biodegradability of fibrin using PBS and TrypleSelect $1 \mathrm{X}$ for 21 days of incubation (A); and percentage of degradation (B). ${ }^{*} p<0.05$ indicates statistical significance.

with $1 \mu \mathrm{g} / \mathrm{ml}$ of ascorbic acid compared to the control. There was no significant difference between the aggrecan and type 1 collagen and the control. This study shows that $3 \mu \mathrm{g} / \mathrm{ml}$ of ascorbic acid was the optimal concentration to induce the chondrogenesis of ASCs.

\section{DISCUSSION}

Our results show that the ASCs had a plastic adherence capacity with a similar shape of cells between the groups (fibroblast-like). We therefore continued to investigate the effect of ascorbic acid on the chondrogenic nature of human ASCs cultured in a human fib- rin scaffold. According to the results, the fibrin substrate along with ascorbic acid has potency regarding cell attachment and supporting chondrogenic differentiation.

Ascorbic acid is often combined with serum as a micronutrient to increase the proliferation rate of $\mathrm{ASCs}^{24}$. Fibrin was fabricated as a scaffold for tissue engineering purposes since fibrin contains a growth factor to initiate cell proliferation. Kobayashi et al., ${ }^{25}$ evaluated the angiogenesis protein in platelet-rich fibrin (PRF) and found that fibrin contains a vascular endothelial growth factor (VEGF) and platelet-derived growth factor (PDGF-BB) ${ }^{25}$. Another study reported 


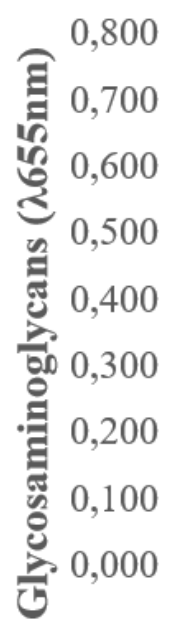

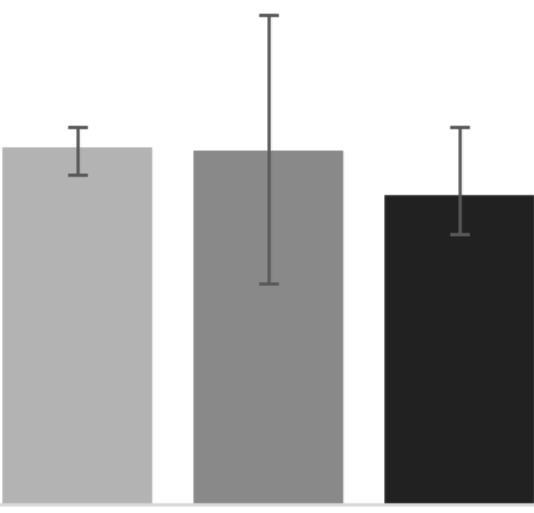

Fibrin

DMFA + 0 ug/ml LAA2P $\square$ DMFA + 1 ug/ml LAA2P

- DMFA + $3 \mathrm{ug} / \mathrm{ml}$ LAA2P - DMFA + $6 \mathrm{ug} / \mathrm{ml}$ LAA2P

Figure 5: Glycosaminoglycans content.

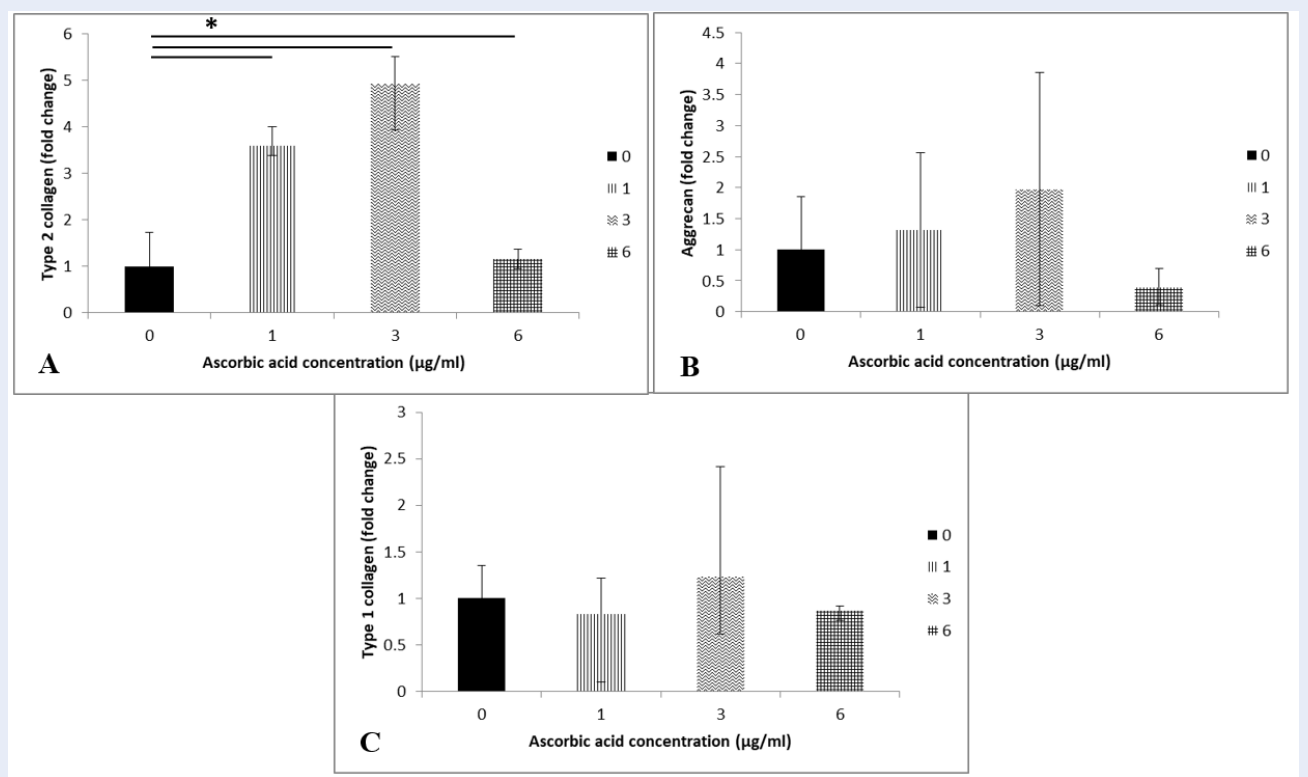

Figure 6: mRNA expression of type 2 collagen, aggrecan and type 1 collagen cultured on fibrin substrate. ${ }^{*} p<0.05$ indicates statistical significance. 
that rabbit PRF stimulated cellular migration and the proliferation of meniscocytes ${ }^{26}$. The combination of ascorbic acid supplementation and fibrin substrate may act synergistically to improve cell migration, proliferation and chondrogenic differentiation.

Regarding chondrogenic differentiation, collagen, aggrecan and GAG are the main components of the extracellular matrix (ECM) involved in both cell proliferation and the differentiation of chondrocytes. Chondrogenesis involves the condensation and deposition of ECM formation ${ }^{27}$. Ascorbic acid induces ATDC5 cell differentiation by promoting the formation of a collagenous matrix mediated by the activation of the ERK signaling pathway ${ }^{13}$. Our study shows that the ASCs cultured on fibrin substrate supplemented by $3 \mu \mathrm{g} / \mathrm{ml}$ of ascorbic acid had a higher expression of type 2 collagen, aggrecan, and GAG, indicating that the proper concentration of ascorbic acid and fibrin had an effect in terms of supporting the ASCs chondrogenesis. It has been reported that PRF contains transforming growth factor beta (TGF- $\beta)^{\mathbf{2 8}}$. TGF- $\beta$ has an important role in regulating chondrogenic differentiation ${ }^{12}$. TGF- $\beta$ secreted by fibrin activates the Smad signaling pathway while ascorbic acid activates the ERK signaling pathway. Both mechanisms lead to the chondrogenic differentiation of human ASCs. Up-regulated type 2 collagen and GAG of chondrocyte cultured on fibrin were also reported by Chien et al. ${ }^{28}$. Another study showed that human PRF stimulated proliferation and induced the aggrecan synthesis of ASCs ${ }^{29}$. The presence of GAGs in the cells confirmed chondrogenic differentiation ${ }^{12,30}$. In contrast, an osteogenic marker, specifically type $1 \mathrm{col}-$ lagen, was expressed in a low concentration, indicating that osteogenic differentiation did not occur.

This report shows that ascorbic acid also has the potential to induce chondrogenesis in the ASCs cultured on the fibrin substrate. Although the pathway of ascorbic acid and fibrin to induce chondrogenesis in this study was unclear, there were previous studies explaining the role of both pathways. In addition, the results need to be evaluated due to our study having many limitations including a small sample size and no evaluation of the protein level. Regardless, these results indicate the potential of ascorbic acid and fibrin substrate in the differentiation of human ASCs for cartilage tissue engineering application.

\section{CONCLUSIONS}

It can be concluded that the supplementation of 3 $\mu \mathrm{g} / \mathrm{ml}$ of ascorbic acid for human adipose-derived stem cells cultured on fibrin substrate promotes type 2 collagen expression is optimal. However, it is too early to state that the cells lead to chondrogenic differentiation since the aggrecan expression is not significantly increased.

\section{ABBREVIATIONS}

None.

\section{ACKNOWLEDGMENTS}

The authors highly appreciate the Hayandra Peduli Foundation, Hayandra Laboratory, where the research was facilitated, and are greatly indebted for the cooperation of the lipoaspirate donor for their lipoaspirate donation.

\section{AUTHOR'S CONTRIBUTIONS}

(I) Conception and design: Imam Rosadi; Karina Karina; (II) Administrative support: Imam Rosadi; Karina Karina; Viol Dhea Kharisma; (III) Provision of study materials or patients: Karina Karina; (IV) Collection and assembly of data: Imam Rosadi; Arif Nur Muhammad Ansori; (V) Data analysis and interpretation: Imam Rosadi; (VI) Manuscript writing: Imam Rosadi; Viol Dhea Kharisma, Arif Nur Muhammad Ansori; (VII) Final approval of manuscript: All authors.

\section{FUNDING}

None.

\section{AVAILABILITY OF DATA AND MATERIALS}

Data and materials used and/or analyzed during the current study are available from the corresponding author on reasonable request.

\section{ETHICS APPROVAL AND CONSENT TO PARTICIPATE}

Not applicable.

\section{CONSENT FOR PUBLICATION}

Not applicable.

\section{COMPETING INTERESTS}

The authors declare that they have no competing interests.

\section{REFERENCES}

1. Bi S, Nie Q, Wang WQ, Zhu YL, Ma XM, Wang CM. Human Umbilical Cord Mesenchymal Stem Cells Therapy for Insulin Resistance: A Novel Strategy in Clinical Implication. Current Stem Cell Research \{\&amp; \}amp; Therapy. 2018;13(8):658-64. PMID: 30095059. Available from: 10.2174/ $1574888 X 13666180810154048$. 
2. Wankhade UD, Shen $M$, Kolhe $R$, Fulzele $S$. Advances in Adipose-Derived Stem Cells Isolation, Characterization, and Application in Regenerative Tissue Engineering . Stem Cells Int. 2016;2016:3206807. PMID: 26981130. Available from: $10.1155 / 2016 / 3206807$

3. Taylor HS. Therapeutic endometrial regeneration: clinical application of bone marrow-derived stem cells. BJOG. 2020;127(5):561-561. PMID: 31925867. Available from: 10. 1111/1471-0528.16088.

4. Mazini L, Rochette L, Amine M, Malka G. Regenerative Capacity of Adipose Derived Stem Cells (ADSCs), Comparison with Mesenchymal Stem Cells (MSCs) . Int J Mol Sci. 2019;20(10):2523. PMID: 31121953. Available from: 10.3390/ ijms20102523.

5. Zuk PA, Zhu M, Mizuno H, Huang J, Futrell JW, Katz AJ, et al. Multilineage cells from human adipose tissue: implications for cell-based therapies. Tissue Eng. 2004;7(2):211-28. PMID: 11304456. Available from: 10.1089/107632701300062859.

6. Zuk PA. The adipose-derived stem cell: looking back and looking ahead. Mol Biol Cell. 2010;21(11):1783-7. PMID: 20375149. Available from: 101091/mbc.e09-07-0589.

7. Singh A, Yadav CB, Tabassum N, Bajpeyee AK, Verma V. Stem cell niche: dynamic neighbor of stem cells. European Journal of Cell Biology. 2019;98(2-4):65-73. PMID: 30563738. Available from: 10.1016/j.ejcb.2018.12.001.

8. Govoni M, Muscari C, Bonafè F, Morselli PG, Cortesi M, Dallari $D$. A brief very-low oxygen tension regimen is sufficient for the early chondrogenic commitment of human adiposederived mesenchymal stem cells. Advances in Medical Sciences. 2021;66(1):98-104. PMID: 33461101. Available from: 10.1016/j.advms.2020.12.005.

9. Rosadi I, Karina K, Rosliana I, Sobariah S, Afini I, Widyastuti T, et al. The Effect of Human Platelet-Rich Plasma and L-Ascorbic Acid on Morphology, Proliferation, and Chondrogenesis Ability towards Human Adipose-Derived Stem Cells. Molecular and Cellular Biomedical Sciences. 2019;3(1):26. Available from: $10.21705 / \mathrm{mcbs} . v 3 \mathrm{i} 1.43$

10. Wahyuningsih KA, Karina K, Rosadi I, Rosliana I, Subroto WR. Effect of ascorbic acid on morphology of post-thawed human adipose-derived stem cells. Stem Cell Investig. 2020;7:16. PMID: 33110914. Available from: 10.21037/sci-2020-011.

11. Langenbach $F$, Handschel J. Effects of dexamethasone, ascorbic acid and $\beta$-glycerophosphate on the osteogenic differentiation of stem cells in vitro. Stem Cell Res Ther. 2013;4(5):117. PMID: 24073831. Available from: 10.1186/scrt328.

12. Rosadi I, Karina K, Rosliana I, Sobariah S, Afini I, Widyastuti $\mathrm{T}$, et al. In vitro study of cartilage tissue engineering using human adipose-derived stem cells induced by plateletrich plasma and cultured on silk fibroin scaffold. Stem Cell Res Ther. 2019;10(1):369. PMID: 31801639. Available from: 10.1186/s13287-019-1443-2.

13. Temu TM, Wu KY, Gruppuso PA, Phornphutkul C. The mechanism of ascorbic acid-induced differentiation of ATDC5 chondrogenic cells. Am J Physiol Endocrinol Metab. 2010;299(2):E325-34. Available from: 101152/ajpendo001452010.

14. Wu YK, Tu YK, Yu J, Cheng NC. The Influence of Cell Culture Density on the Cytotoxicity of Adipose-Derived Stem Cells Induced by L-Ascorbic Acid-2-Phosphate. Sci Rep. 2020;10(1):104. PMID: 31919399. Available from: 10.1038/ s41598-019-56875-0

15. Valenti MT, Zanatta M, Donatelli L, Viviano G, Cavallini C Scupoli MT. Ascorbic acid induces either differentiation or apoptosis in MG-63 osteosarcoma lineage. Anticancer Research. 2014;34(4):1617-27. PMID: 24692690.

16. Ahmed TA, Dare EV, Hincke M. Fibrin: a versatile scaffold for tissue engineering applications. Tissue Eng Part B Rev. 2008;14(2):199-215. Available from: 10.1089/ten.teb.2007. 0435.

17. Rosadi I, Moegni KF, Ad S, Sobariah S, Rosliana I, Wahyuningsih KA. Fibrin Substrate Supports Chondrogenesis of Adipose-
Derived Stem Cells Supplemented by Human Platelet-Rich Plasma and L-Ascorbic Acid 2-Phosphate. Cytotherapy. 2020;22(5):181. Available from: 10.1016/j.jcyt.2020.03.380.

18. Wu CL, Lee SS, Tsai CH, Lu KH, Zhao JH, Chang YC. Platelet-rich fibrin increases cell attachment, proliferation and collagenrelated protein expression of human osteoblasts. Australian Dental Journal. 2012;57(2):207-12. PMID: 22624763. Available from: 10.1111/j.1834-7819.2012.01686.x.

19. Hunter CJ, Mouw JK, Levenston ME. Dynamic compression of chondrocyte-seeded fibrin gels: effects on matrix accumulation and mechanical stiffness. Osteoarthritis and Cartilage. 2004;12(2):117-30. PMID: 14723871. Available from: 10.1016/j.joca.2003.08.009.

20. Moegni KF, Rosliana I, Remelia M, Rosadi I, Sobariah S, Afini I. Stromal vascular fraction (SVF) therapy for treatment of various diseases: delivering safety of the first patented svf technique in indonesia. Cytotherapy. 2019;21(5):86. Available from: 10.1016/j.jcyt.2019.03.511.

21. Karina K, Rosliana I, Rosadi I, Schwartz R, Sobariah S, Afini I, et al. Safety of Technique and Procedure of Stromal Vascular Fraction Therapy: From Liposuction to Cell Administration. Scientifica (Cairo). 2020;2020:2863624. PMID: 32695550. Available from: 10.1155/2020/2863624.

22. Kobayashi M, Kawase T, Horimizu M, Okuda K, Wolff LF, Yoshie H. A proposed protocol for the standardized preparation of PRF membranes for clinical use. Biologicals. 2012;40(5):3239. PMID: 22841724. Available from: 10.1016/j.biologicals.2012. 07.004 .

23. Livak KJ, Schmittgen TD. Analysis of relative gene expression data using real-time quantitative $P C R$ and the $2(-\Delta \Delta C(T))$ Method. Methods (San Diego, Calif). 2001;25(4):402-8. PMID: 11846609. Available from: 10.1006/meth.2001.1262.

24. Zhang P, Li J, Qi Y, Zou Y, Liu L, Tang $X$, et al. Vitamin $C$ promotes the proliferation of human adiposederived stem cells via p53-p21 pathway. Organogenesis. 2016;12(3):143-151. PMID: 27231022. Available from: 101080/ 1547627820161194148 .

25. Kobayashi M, Kawase T, Okuda K, Wolff LF, Yoshie H. In vitro immunological and biological evaluations of the angiogenic potential of platelet-rich fibrin preparations: a standardized comparison with PRP preparations. Int J Implant Dent. 2015;1(1):31. PMID: 27747653. Available from: 10.1186/ s40729-015-0032-0.

26. Wong CC, Kuo TF, Yang TL, Tsuang YH, Lin MF, Chang CH, et al. Platelet-Rich Fibrin Facilitates Rabbit Meniscal Repair by Promoting Meniscocytes Proliferation, Migration, and Extracellular Matrix Synthesis. Int J Mol Sci. 1722;18(8):1722. PMID: 28783120. Available from: 10.3390/ijms18081722.

27. Park YB, Seo S, Kim JA, Heo JC, Lim YC, Ha CW. Effect of chondrocyte-derived early extracellular matrix on chondrogenesis of placenta-derived mesenchymal stem cells. Biomedical Materials (Bristol, England). 2015;10(3):035014. PMID: 26107298. Available from: 10.1088/1748-6041/10/3/ 035014.

28. Chien $\mathrm{CS}$, Ho HO, Liang YC, Ko PH, Sheu MT, Chen $\mathrm{CH}$. Incorporation of exudates of human platelet-rich fibrin gel in biodegradable fibrin scaffolds for tissue engineering of cartilage. Journal of Biomedical Materials Research Part B, Applied Biomaterials. 2012;100(4):948-55. PMID: 22279009. Available from: $10.1002 / \mathrm{jbm} . b .32657$.

29. Souza FG, Fernandes BL, Rebelatto CL, Aguiar AM, Fracaro L, Brofman PR. Proliferation and differentiation of stem cells in contact with eluate from fibrin-rich plasma membrane. Revista Brasileira de Ortopedia. 2017;53(1):45-52. PMID: 29367906. Available from: 10.1016/j.rboe.2017.12.004.

30. Almeida PN. Increased extracellular matrix deposition during chondrogenic differentiation of dental pulp stem cells from individuals with neurofibromatosis type 1 : an in vitro $2 \mathrm{D}$ and 3D study. Orphanet J Rare Dis. 2018;13(1):98. PMID: 29941005. Available from: 10.1186/s13023-018-0843-1. 
Ready to submit your manuscript? Choose Biomedpress and benefit from:

- Fast, convenient online submission

- Through peer-review by experienced researchers

- Rapid publication on acceptance

- Free of charge (without publication fees)

Learn more http://www.biomedpress.org/journals/
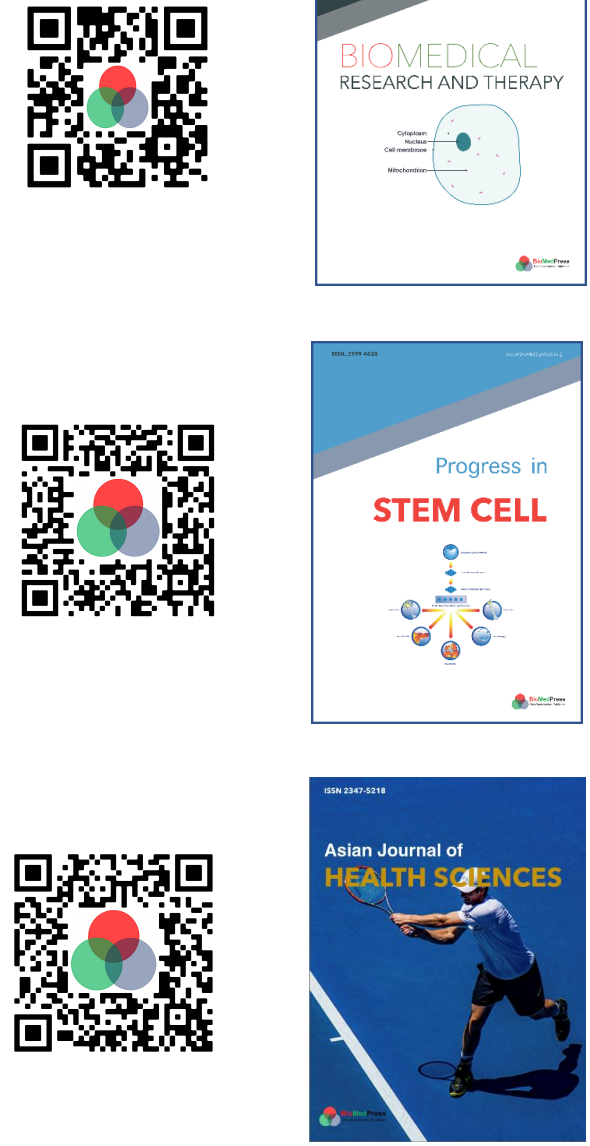

Asian Journal of Health Sciences

ISSN: 2347-5218

Indexed: Google Scholar

Acceptance Rate (2020): 72.89\%

Article Publishing Charge: Free

Submission to first editorial decision: 16.5 days

Biotechnological Research

ISSN: 2395-6763

Indexed: Google Scholar

Acceptance Rate (2020): $67.02 \%$

Article Publishing Charge: Free

Submission to first editorial decision: 28.5 days 